\title{
Propiedades y durabilidad del cemento con adición de metacaolín: mortero y hormigón
}

\author{
Properties and durability of metakaolin blended cements: \\ mortar and concrete
}

\author{
$\underline{\text { Rafik Abbas }}^{(*)}$, Salah A. Abo-El-Enein ${ }^{(* *)}$, El-Sayed Ezzat ${ }^{(* * *)}$
}

Recepción/Received: 11-II-09

Aceptación/Accepted: 9-XI-09

Publicado online/Online publishing: 17-XII-10

\section{RESUMEN}

En este trabajo se estudia el efecto del metacaolín sobre las prestaciones del hormigón. Las probetas curadas a 360 y 90 días se sometieron a ensayos de resistencia a compresión y de tracción indirecta respectivamente. Se hizo un seguimiento de la resistencia a la compresión de los materiales ante el ataque de sales (soluciones de cloruro y de sulfato-cloruro) y, se midió la penetración de cloruros y la capacidad de los hormigones de inmovilizar estos iones. Los resultados se compararon con los obtenidos con hormigones elaborados con cemento pórtland ordinario (OPC) y, con cemento de calor de hidratación moderado (tipo II). El MK resultó influir muy positivamente en la resistencia del hormigón a 28 días debido a la mejora de la microestructura del cemento hidratado. La sustitución de cemento por metacaolín aumentó la resistencia del hormigón al ataque de cloruros. El hormigón con metacaolín demostró ser más duradero en entornos de sulfato-cloruro que los hormigones elaborados con OPC o con cemento de tipo II. Los perfiles de concentración de cloruros a distintas profundidades y la diferencia entre los contenidos de cloruro libre y total, mostraron claramente que el cemento con metacaolín reducía la penetración de cloruros en el hormigón y, aumentaba su capacidad para combinar con iones cloruro. La conclusión general fue que podía fabricarse material puzolánico utilizable, mediante la activación térmica del caolín local.

Palabras clave: cemento con adiciones, metacaolín, ataque sulfatos-cloruros, penetración cloruros.
SUMMARY

This article explores the effect of metakaolin, a pozzolan, on concrete performance. Compressive and splitting tensile strength were found for specimens cured for up to 360 and 90 days, respectively. Changes were recorded in the compressive strength of specimens exposed to salt (chloride and sulfatechloride solutions), and chloride penetration and binding capacity were measured. The findings were compared to the results for concrete prepared with ordinary Portland (OPC) and moderate heat of hydration (Type II) cement. MK was found to have a very positive effect on 28-day concrete strength, due to microstructure improvement of the hydrated cement. Replacing cement with metakaolin effectively raised concrete resistance to chloride attack. Concrete containing metakaolin proved to be substantially more durable in sulfate-chloride environment.

Keywords: blended cement, metakaolin, sulfate-chloride attack, chloride penetration.

\footnotetext{
(*) Alexandria University, Alexandria (Egipto).

(**) Ein Shams University, Cairo (Egipto).

(***) Suez Cement Company, Suez (Egipto).
} 


\section{INTRODUCCIÓN}

Los materiales puzolánicos como el humo de sílice (HS) y las cenizas volantes (CV) son componentes esenciales del hormigón de altas prestaciones. Cuando se emplean como aditivos minerales en el hormigón de altas prestaciones, pueden mejorar la resistencia y la durabilidad de dicho material. En los últimos años ha crecido el interés por el uso de metacaolín (MK) como adición mineral con este fin (1-3). Sabir y otros (4) y Siddique y Klaushave (5) han publicado recientemente monografías amplias sobre el uso del metacaolín como sustituto puzolánico parcial del cemento y, su efecto sobre las propiedades de morteros y hormigones.

El metacaolín es un material silicoaluminoso activado que se obtiene mediante la calcinación a $650-800{ }^{\circ} \mathrm{C}$ de una arcilla llamada caolín (4). El MK de alta reactividad, un mineral puzolánico sintético, reacciona de forma muy vigorosa con el hidróxido cálcico, lo que mejora de forma significativa las prestaciones del hormigón. Esta sustancia ha demostrado ser una alternativa adecuada al humo de sílice en la formulación de hormigones de alta resistencia o de altas prestaciones $(6,7)$. De hecho, Justice y otros $(8)$ observaron que el MK de alta reactividad producía resultados mejores incluso que el humo de sílice y mejoraba las propiedades del hormigón a la vez que garantizaba una buena trabajabilidad. Con una relación agua-conglomerante de entre 0,36 y 0,38, el hormigón con MK precisa desde un 25 hasta un $35 \%$ menos de aditivo superplastificante que el material que lleva HS para lograr un escurrimiento en el cono de entre 120 y $180 \mathrm{~mm}(9,10)$. El primero tiene una textura más suave y fragua algo más rápidamente, además de producir menos exudación y permitir un mejor acabado que el hormigón con HS (9-12).

En los hormigones con MK se desarrollan la resistencia a la compresión y a la flexión de forma considerablemente más rápida que en el material convencional y a edades ligeramente más tempranas o idénticas a las del hormigón con HS (9). En hormigones con la misma relación aguamaterial cementante, la resistencia a la compresión aumenta de forma espectacular en todas las edades a medida que se aumenta la proporción (en peso) de MK de alta reactividad en la mezcla $(13,14)$. Justice y Kurtis (15) observaron que la adición de metacaolín incrementaba la resistencia a flexión a edades tempranas (1-3 días) en hasta un $60 \%$. Según Razak y Wong (7), en las probetas de 7 y de 28 días, la incorporación de MK mejoraba la resistencia en un 70 y un $50 \%$, mientras que la sustitución de cemento por MK mejoraba la resistencia en un 67 y un $39 \%$, respectivamente. Además, puede lograrse una resistencia en hormigón de un día de $24 \mathrm{MPa}$ mediante la inclusión de un 10\% de metacaolín en tan sólo $305 \mathrm{~kg} / \mathrm{m}^{3}$ de cemento de tipo I (16). Boddy y otros (14) demostraron que el MK resulta especialmente eficaz a la hora de reducir la velocidad de difusión de los iones cloruro.

\section{INTRODUCTION}

Pozzolanic materials such as silica fume (SF) and fly ash (FA) are essential components in high performance concrete. When used as mineral admixtures in high performance concrete, these materials can improve concrete strength or durability or both. Interest has grown in recent years in the use of metakaolin (MK) as a mineral admixture for this purpose (1-3). Sabir et al. (4) and Siddique and Klaushave (5) recently published comprehensive reviews on the use of metakaolin as a partial pozzolanic replacement for cement and its effect on mortar and concrete properties.

Metakaolin is a thermally activated aluminosilicate material obtained by calcining kaolin clay at 650-800 ${ }^{\circ} \mathrm{C}$ (4). High reactivity $M K$, an artificial pozzolanic mineral, reacts aggressively with calcium hydroxide, significantly enhancing concrete performance. This substance has been shown to be an acceptable alternative to silica fume in the formulation of high strength/performance concrete $(6,7)$. Indeed, high reactivity $M K$ was reported by Justice et al. (8) to yield even better results than silica fume, improving concrete properties while ensuring good workability. At a water/binder ratio of 0.36 to $0.38, M K$ concrete requires 25 to $35 \%$ less high-range waterreducing admixture than SF concrete to achieve a comparable slump of 120 to $180 \mathrm{~mm}(9,10)$. The former has a smoother texture, sets somewhat faster, generates less bleed water and affords a better finish than SF concrete (9-12).

Both compressive and flexural strength develop in MKcontaining concrete significantly faster than in the conventional material and at slightly earlier or the same ages as in concrete made with SF-blended cement (9). In concretes with the same water/binder ratio, compressive strength increased dramatically at all ages with increasing replacement ratios (wt) of high reactivity MK $(13,14)$. Justice and Kurtis (15) reported that the addition of metakaolin raised early age (1-3-day) flexural strength by as much as $60 \%$. According to Razak and Wong (7), adding MK improved strength by 70 and 50\%, while replacing cement with MK enhanced strength by 67 and $39 \%$ in 7- and 28-day specimens, respectively. Moreover, one-day strength of $24 \mathrm{MPa}$ can be attained by adding $10 \%$ metakaolin to only $305 \mathrm{~kg} / \mathrm{m}^{3}$ of Type I cement (16). Boddy et al. (14) showed that $M K$ is particularly effective in reducing the chloride ion diffusion rate. 
Otros parámetros de durabilidad, como son la reacción álcali-sílice, la resistencia a sulfatos y la resistencia a la corrosión, mejoran hasta un $25 \%$ al aumentar las proporciones de MK. Ramlochan y Thomas (17) observaron que los morteros elaborados con cualquier porcentaje (entre un 5 y un 25\%) de MK de alta reactividad como sustitución parcial de cementos con un elevado contenido en $C_{3} A\left(\approx 10 \%\right.$ de $C_{3} A$ ) pueden considerarse moderadamente resistentes a los sulfatos, mientras que los elaborados con $\mathrm{MK}$ de alta reactividad y un cemento con un contenido moderado o bajo de $\mathrm{C}_{3} \mathrm{~A}\left(<6 \%\right.$ de $\mathrm{C}_{3} \mathrm{~A}$ ) pueden considerarse altamente resistentes a los sulfatos. Sin embargo, en las probetas de la edad de seis meses o más, se observó que a niveles insuficientes de metacaolín de alta reactividad se llegaba incluso a reducir la resistencia a sulfatos de algunos cementos. Estos autores llegaron a la conclusión de que puede ser necesario un $15 \%$ como mínimo de MK de alta reactividad para conseguir la resistencia a sulfatos a largo plazo, en función del contenido en $\mathrm{C}_{3} \mathrm{~A}$ del cemento. Asimismo, la adición de hasta un $15 \%$ de metacaolín mejoró la resistencia a la corrosión de la armadura de acero (18). El rápido consumo del hidróxido cálcico $\left(\mathrm{Ca}(\mathrm{OH})_{2}\right)$ y el aumento del $\mathrm{C}-\mathrm{S}-\mathrm{H}$ y de la gehlenita hidratada $\left(\mathrm{C}_{2} \mathrm{ASH}_{8}\right)$ generados dan lugar al refinamiento de la estructura porosa, que se ha identificado como el principal mecanismo causante de la mejora de las propiedades del hormigón observadas al añadir MK $(19,20)$.

El MK estudiado hasta la fecha suele constar de un 50$55 \%$ de $\mathrm{SiO}_{2}$ y un $40-45 \%$ de $\mathrm{Al}_{2} \mathrm{O}_{3}$ (21). Todo $\mathrm{MK}$ que tenga esta composición se considera altamente reactivo (1). Arikan y otros (22) afirman pueden fabricarse adiciones eficaces de minerales mediante la activación térmica de caolín crudo con un contenido mínimo del 21,5\% de $\mathrm{Al}_{2} \mathrm{O}_{3}$ y un contenido máximo del $55,0 \%$ de $\mathrm{SiO}_{2}$. Por otra parte, el alza de los costes de la construcción que supone el aumento del precio de los materiales puzolánicos, ha provocado una reorientación de la investigación hacia el llamado metacaolín pobre, que se caracteriza por un bajo contenido de $\mathrm{Al}_{2} \mathrm{O}_{3}$ y un elevado contenido de $\mathrm{SiO}_{2}(23,24)$. No obstante, son muy pocos los trabajos publicados sobre las prestaciones del hormigón fabricado con caolín pobre.

El presente estudio tiene por objeto verificar la aplicabilidad del metacaolín local como sustitutivo del cemento en el hormigón, analizando para ello las propiedades mecánicas, la resistencia al ataque de cloruros y de sulfato-cloruro y la penetración de cloruros. Los resultados se comparan con los obtenidos con hormigones elaborados con cemento Pórtland ordinario (OPC) y con cemento de calor de hidratación moderado (tipo II). La elección del hormigón con cemento de tipo II como control se debe a su elevada resistencia al sulfato-cloruro.
Other durability parameters, such as the alkali-silica reaction, sulfate resistance and corrosion resistance, improve with increasing $M K$ replacement ratios, up to 25\%. Ramlochan and Thomas (17) reported that mortar specimens containing any percentage of high reactivity MK (5-25\%) as a partial replacement for a high- $C_{3} A$ cement $\left(\approx 10 \% \quad C_{3} A\right)$ may be considered to be "moderately sulfate resistant"; mortar specimens made with high reactivity $M K$ and a moderate or low $C_{3} A$ cement $\left(<6 \% C_{3} A\right)$ can be regarded to be "highly sulfate resistant". In 6-month or older specimens, however, insufficient levels of high reactivity metakaolin were observed to even reduce the sulfate resistance of some cements. These authors concluded that $15 \%$ or more high reactivity $M K$ may be required for long-term sulfate resistance, depending on the $C_{3} A$ content of the cement. Furthermore, the addition of up to $15 \%$ metakaolin improved the corrosion resistance of reinforcing steel (18). The rapid consumption of calcium hydroxide $(\mathrm{CH})$ and the increase in the amount of $\mathrm{C}-\mathrm{S}-\mathrm{H}$ and hydrated gehlenite $\left(\mathrm{C}_{2} \mathrm{ASH}_{8}\right)$ generated lead to refinement of the pore structure, identified as the main mechanism governing the improvement of concrete properties observed with the addition of MK $(19,20)$.

The MK studied to date typically consists of $50-55 \% \mathrm{SiO}_{2}$ and $40-45 \% \mathrm{Al}_{2} \mathrm{O}_{3}$ (21). Any $\mathrm{MK}$ with this composition is regarded to be highly reactive (1). Arikan et al. (22) claimed that effective mineral additions could be processed by thermally activating raw kaolin having at least $21.5 \% \mathrm{Al}_{2} \mathrm{O}_{3}$ and less than $55.0 \% \mathrm{SiO}_{2}$. Ever higher construction costs due to the rising price of pozzolanic materials, however, turned researcher interest to socalled poor metakaolin, characterized by a low $\mathrm{Al}_{2} \mathrm{O}_{3}$ and high $\mathrm{SiO}_{2}$ content $(23,24)$. Nevertheless, very few papers have been published on the performance of concrete based on low-grade kaolin.

The present study aimed to verify the applicability of local metakaolin as a replacement for cement in concrete by testing for strength, salt resistance (i.e., chloride and sulfate-chloride attack) and chloride penetration. The findings were compared to the results for concrete made with ordinary Portland (OPC) and moderate heat of hydration (Type II) cement. Type II concrete was chosen as a control for its high sulfate-chloride resistance. 


\section{EXPERIMENTAL}

\subsection{Materiales, composición de la mezcla y preparación de las probetas}

Para este estudio se emplearon dos tipos de cemento Pórtland: CEM I 32,5 y cemento de calor de hidratación moderado (tipo II), fabricados en las plantas de Suez y Assiut, respectivamente. Las composiciones químicas de ambos tipos de cemento se muestran en la Tabla 1. Según el cálculo de Bogue, los compuestos $\mathrm{C}_{3} \mathrm{~S}, \mathrm{C}_{2} \mathrm{~S}, \mathrm{C}_{3} \mathrm{~A}$ y $\mathrm{C}_{4} \mathrm{AF}$ suponían el $65,6 \%, 7,2 \%, 6,8 \%$ y $9,6 \%$, respectivamente, del cemento CEM I. La superficie específica era de $315 \mathrm{~m}^{2} / \mathrm{kg}$ en el caso del OPC y de $306 \mathrm{~m}^{2} / \mathrm{kg}$ en el del cemento de tipo II. La composición química de ambos tipos de MK (el MKH y el MKS) empleados como sustitutivos del cemento también se facilita en la Tabla 1. La densidad específica del MK, preparado según se ha indicado en un artículo anterior (20), era de 2,58, y su superficie específica, de $315 \mathrm{~m}^{2} / \mathrm{kg}$. Se empleó como árido fino arena silícea natural con un módulo de finura de 2,6 y una densidad específica de 2,63, y como árido grueso caliza triturada con un tamaño de grano máximo de $20 \mathrm{~mm}$ y una densidad específica de 2,55. Como superplastificante se utilizó el Sikament $163 \mathrm{M}$, un aditivo polimérico de tipo F (norma ASTM C 494), con un contenido de sólidos del $37 \%$.

\section{EXPERIMENTAL}

\subsection{Materials, mix composition and specimen preparation}

Two types of commercial Portland cements were used in this study, CEM I 32.5 and moderate heat of hydration (Type II) cement, manufactured by the Suez and Assiut Plants, respectively. The chemical compositions of both types of cement are shown in Table 1. Further to the Bogue calculation, $C_{3} S, C_{2} S, C_{3} A$ and $C_{4} A F$ accounted for $65.6,7.2,6.8$ and $9.6 \%$, respectively of CEM I cement. Blaine fineness was found to be $315 \mathrm{~m}^{2} / \mathrm{kg}$ in OPC and $306 \mathrm{~m}^{2} / \mathrm{kg}$ in Type II cement. The chemical composition of both types of MK (i.e., MKH and MKS) used as cement replacements is also given in Table 1 . The specific gravity of the $M K$, which was prepared as described in a prior paper (20), was 2.58 and its specific surface 315 $\mathrm{m}^{2} / \mathrm{kg}$. The fine aggregate used was natural siliceous sand with a fineness modulus of 2.6 and specific gravity of 2.63. The coarse aggregate used was crushed limestone with a maximum size of $20 \mathrm{~mm}$ and a specific gravity of 2.55. Sikament 163M, an ASTM C 494 type $F$ polymeric superplasticizer, with a $37 \%$ solids content, was used throughout.

Tabla 1 / Table 1

Composición química del OPC, del cemento de tipo II y de los metacaolines. Chemical composition of OPC, Type II cement and metakaolin.

\begin{tabular}{|c|c|c|c|c|}
\hline Óxidos / Oxides (\%) & OPC & Tipo II / Type II & MKH & MKS \\
\hline $\mathrm{CaO}$ & 63.76 & 63.78 & 2.48 & 1.83 \\
\hline $\mathrm{SiO}_{2}$ & 19.75 & 20.45 & 51.28 & 68.88 \\
\hline $\mathrm{Al}_{2} \mathrm{O}_{3}$ & 4.58 & 4.77 & 21.4 & 12.02 \\
\hline $\mathrm{Fe}_{2} \mathrm{O}_{3}$ & 3.17 & 4.32 & 9.36 & 6.96 \\
\hline $\mathrm{MgO}$ & 3.15 & 1.6 & 1.75 & 1.24 \\
\hline $\mathrm{SO}_{3}$ & 2.99 & 2.9 & 2.9 & 0.16 \\
\hline $\mathrm{K}_{2} \mathrm{O}$ & 0.22 & 0.13 & 0.69 & 0.99 \\
\hline $\mathrm{Na}_{2} \mathrm{O}$ & 0.27 & 0.17 & 0.18 & 1.03 \\
\hline $\mathrm{Cl}$ & 0.01 & 0.01 & 8.06 & 0.74 \\
\hline $\mathrm{P.C.}$ & 3.44 & 2.16 & & 4.85 \\
\hline
\end{tabular}

Se prepararon cuatro mezclas de hormigón con una relación agua-cemento de 0,4 utilizando cuatro materiales cementantes distintos: OPC, cemento de tipo II, $75 \%$ de OPC con $25 \%$ de $\mathrm{MKH}$ y $75 \%$ de OPC con $25 \%$ de MKS. En la Tabla 2 se detalla la composición de las mezclas de hormigón, que se prepararon en una hormigonera de tambor basculante de 0,15 $\mathrm{m}^{3}$. Se añadió el superplastificante a todas las mezclas en la proporción necesaria para obtener un escurrimiento en el cono de $175 \pm$ $25 \mathrm{~mm}$. Se prepararon probetas cúbicas $(100 \times 100 \times 100$ $\mathrm{mm}$ ) y cilíndricas (75 mm de diámetro por $150 \mathrm{~mm}$ de alto, y $100 \mathrm{~mm}$ de diámetro por $200 \mathrm{~mm}$ de alto) en
Four concrete mixes were prepared at a $\mathrm{w} / \mathrm{c}$ ratio of 0.4 using four different binders (OPC, Type II cement, 75\% OPC-25\% MKH and 75\% OPC-25\% MKS). Concrete mix specifics are given in Table 2. The mixes were prepared using a 0.15-cubic metre tilting drum mixer. The superplasticizer was added to all mixes in proportions as required to achieve a $175 \pm 25-\mathrm{mm}$ slump. Cubic

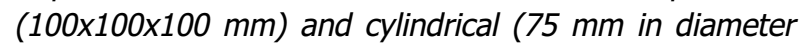
by $150 \mathrm{~mm}$ high and $100 \mathrm{~mm}$ in diameter by $200 \mathrm{~mm}$ high) specimens were cast in steel moulds for each mix and compacted on a vibrating table. These specimens were covered with wet burlap for 24 hours and then 
moldes de acero para cada muestra y se compactaron en una mesa de sacudidas. Dichas probetas se cubrieron con arpillera húmeda durante 24 horas antes de sacarlas de sus moldes. Todas ellas se curaron en agua del grifo a 23 $\pm 2{ }^{\circ} \mathrm{C}$ durante 28 días. Cada tipo de probeta cúbica se dividió posteriormente en tres grupos. El primero se conservó en agua del grifo, el segundo se sumergió en una solución de cloruro $(\mathrm{NaCl}$ al $3 \%$ ) y el tercero se mantuvo en un entorno con sulfato-cloruro $\left(\mathrm{Na}_{2} \mathrm{SO}_{4}\right.$ al $5 \%+\mathrm{NaCl}$ al $3 \%$ ), en todos los casos durante 360 días. Las soluciones y el agua del grifo se sustituyeron a los 7 y 14 días y, posteriormente, cada 30 días hasta el fin del experimento. removed from the moulds. All concrete specimens were cured in tap water at $23 \pm 2{ }^{\circ} \mathrm{C}$ for 28 days. Each type of concrete cube specimen was subsequently divided in three sets. The first was stored in tap water, the second immersed in a chloride solution (3.0\% $\mathrm{NaCl})$ and the third kept in a sulfate-chloride environment $\left(5.0 \% \mathrm{Na}_{2} \mathrm{SO}_{4}+\right.$ $3.0 \% \mathrm{NaCl}$ ) for 360 days in all cases. The specimens were placed in fresh solutions after 7 and 14 days and subsequently at 30-day intervals through the end of the experiment. For reasons of readability, the four concrete mixes are referred to hereunder as OPC concrete, Type II concrete, OPC-MKH concrete and OPC-MKS concrete.

Tabla 2 / Table 2

Proporciones de las mezclas de hormigón $\left(\mathrm{kg} / \mathrm{m}^{3}\right)$.

Concrete mix proportions, $\mathrm{kg} / \mathrm{m}^{3}$.

\begin{tabular}{|c|c|c|c|c|c|c|c|c|c|}
\hline \multirow{2}{*}{ Mezcla / Mix } & \multicolumn{4}{|c|}{ Tipo de conglomerante / Binder type } & \multirow{2}{*}{$\begin{array}{l}\text { Árido finol } \\
\text { Fine Agg }\end{array}$} & \multirow{2}{*}{$\begin{array}{c}\text { Árido } \\
\text { grueso / } \\
\text { CoarseAgg }\end{array}$} & \multirow{2}{*}{$\underset{W / B \mid}{\text { Agua-m.c } I}$} & \multirow{2}{*}{ S.P. (\%) } & \multirow{2}{*}{$\begin{array}{c}\text { Escurrimiento } \\
\text { (mm) / Slump } \\
\text { (mm) }\end{array}$} \\
\hline & OPC & Tipo II & MKH & MKS & & & & & \\
\hline OPC & 400 & - & - & - & 670 & 1100 & 0.4 & 1.50 & 155 \\
\hline Tipo II & - & 400 & - & - & 675 & 1100 & 0.4 & 1.65 & 175 \\
\hline OPC-MKH & 300 & - & 100 & - & 650 & 1100 & 0.4 & 1.15 & 185 \\
\hline OPC-MKS & 300 & - & - & 100 & 650 & 1100 & 0.4 & 1.35 & 195 \\
\hline
\end{tabular}

\subsection{Procedimientos de ensayo}

El calor de hidratación se midió hasta el séptimo día, de acuerdo con el procedimiento indicado en la norma EN 196-9:2003. Este ensayo, que implica una medición ininterrumpida del calor de hidratación del cemento en joules por gramo de cemento, se llevó a cabo con el dispositivo de la AFNOR (Association française de Normalisation). La composición de las muestras de mortero analizadas era conforme a la norma EN 196-1.

A las edades de $3,7,28,90,180,270$ y 360 días se realizaron ensayos de compresión a las probetas sumergidas en agua del grifo. También se midió la resistencia a tracción indirecta de las probetas después de su curado en agua durante 3, 7, 28 y 90 días. Para cada edad se analizaron tres muestras de cada mezcla.

La durabilidad de las cuatro mezclas se comparó en base en la evolución de su resistencia a la compresión y la penetración de cloruros en su interior ante el ataque salino (soluciones de $\mathrm{NaCl}$ al 3,0\% y de $\mathrm{Na}_{2} \mathrm{SO}_{4}$ de $5,0 \%+\mathrm{NaCl}$ al 3,0\%). Asimismo se midió la resistencia a la compresión a los 90 , 180, 270 y 360 días de las probetas sumergidas en las soluciones agresivas mencionadas. Dicha resistencia se expresó como porcentaje de la resistencia inicial (es decir, la resistencia a los 28 días de las probetas curadas en agua).

La resistencia a la penetración de cloruros se determinó a partir de los perfiles de concentración de cloruros de las probetas de hormigón sumergidas en soluciones de cloruro y de sulfato-cloruro. Se relacionó el contenido de

\subsection{Test procedures}

Heat of hydration was measured up to the 7 th day as specified in EN 196-9:2003. This test, which entails continuous measurement of the heat of hydration of cement in joules per gram of cement, was conducted with an AFNOR (Association française de Normalisation) device. The composition of the mortar specimens tested was as set out in EN 196-1.

Compressive tests were conducted on the 3-, 7-, 28-, 90-, 180-, 270- and 360-day specimens immersed in tap water. Splitting tensile strength was also measured in the 3-, 7-, 28- and 90-day water-cured specimens. Three specimens were tested for each mix at each age.

The durability of the four mixes was compared by assessing the changes in their respective compressive strength and chloride ingress under salt attack (3.0\% $\mathrm{NaCl}$ and $5.0 \% \mathrm{Na}_{2} \mathrm{SO}_{4}+3.0 \% \mathrm{NaCl}$ solutions). Compressive strength was also measured in the 90-, 180-, 270- and 360-day specimens immersed in the aforementioned aggressive solutions and expressed as the per cent of the initial strength (i.e., 28-day strength in water-cured specimens).

Resistance to chloride ingress was determined in terms of the chloride concentration profiles for the concrete specimens immersed in chloride and sulfate-chloride solutions. Free (water-soluble) and total (acid-soluble) 
cloruro libre (soluble en agua) y total (soluble en ácidos) con la profundidad de penetración. Las muestras se extrajeron de las probetas cúbicas curadas durante 360 días con una taladradora industrial con una broca de punta de tungsteno (widia) de $20 \mathrm{~mm}$. Se perforaron todos los cubos longitudinalmente en fases de $10 \mathrm{~mm}$ hasta una profundidad total de $50 \mathrm{~mm}$. El polvo recogido en cada intervalo se guardó en bolsas herméticas de plástico hasta su análisis mediante titulación para determinar su contenido de cloru$\operatorname{ros}(25,26)$.

Además, se determinó la resistencia del hormigón a la penetración de iones cloruro según la norma ASTM C 1202-97 en muestras cortadas de las probetas cilíndricas curadas en agua durante 90 días $(100 \mathrm{~mm}$ de diámetro por $200 \mathrm{~mm}$ de alto).

\section{RESULTADOS Y DISCUSIÓN}

\subsection{Calor de hidratación}

La Figura 1 muestra el calor de hidratación a los 7 días para los distintos conglomerantes. Según estos resultados, con la adición de MK se produjo una reducción significativa del calor de hidratación, que fue un 5,6\% inferior de promedio en las mezclas con OPC-MK que en las que solo contenían OPC. Asimismo, los valores relativos al calor de hidratación registrado para ambos hormigones con OPC-MK fueron similares a los observados en el caso del cemento de tipo II. Arikan y otros (22) y Kim y otros (27) observaron que la adición de metacaolín al cemento aumentaba tanto el calor total como la velocidad de liberación de calor, obteniéndose valores de hasta $415 \mathrm{~kJ} / \mathrm{kg}$. Estos resultados se obtuvieron en el caso del MK con un $55 \%$ de $\mathrm{SiO}_{2}$ y un $32-37 \%$ de $\mathrm{Al}_{2} \mathrm{O}_{3}$, es decir, con valores comparables a la composición óptima del MK anteriormente mencionada. Por tanto, el menor calor de hidratación en el hormigón con OPC-MK respecto al hormigón con OPC puede atribuirse a los elevados contenidos de $\mathrm{SiO}_{2}$ y a los bajos contenidos de $\mathrm{Al}_{2} \mathrm{O}_{3}$ tanto del MKH como del MKS. chloride content was plotted versus penetration depth. Samples were obtained from the 360-day cube specimens with an industrial drill fitted with a 20- $\mathrm{mm}$ tungsten-tipped bit. Each cube was drilled longitudinally in 10- $\mathrm{mm}$ stages to a total depth of 50 $\mathrm{mm}$. The powder gathered at each interval was stored in airtight plastic bags until analysed for chloride content by titration $(25,26)$.

In addition, concrete resistance to chloride ion penetration was determined as specified in ASTM C 1202-97 on specimens sliced from the 90-day, watercured (100-mm diameter, 200-mm high) cylindrical specimens.

\section{RESULTS AND DISCUSSION}

\subsection{Heat of hydration}

Figure 1 shows the 7-day heat of hydration findings for the binders. According to these results, the addition of $M K$ significantly reduced the heat of hydration, which was $5.6 \%$ lower on average in OPC-MK than in OPC. Moreover, the heat of hydration values for both OPC$M K$ concretes were similar to the findings for Type II cement. Arikan et al. (22) and Kim et al. (27) reported that adding metakaolin to the cement raised both total heat and rate of heat release, with values of up to 415 $\mathrm{kJ} / \mathrm{kg}$. These results were found for $\mathrm{MK}$ with an $\mathrm{SiO}_{2}$ content of $55 \%$ and an $\mathrm{Al}_{2} \mathrm{O}_{3}$ content of $32-37 \%$, i.e., comparable to the aforementioned optimum composition of MK. Therefore, the lower heat of hydration in the $O P C-M K$ than in the OPC concrete is attributable to the high $\mathrm{SiO}_{2}$ and low $\mathrm{Al}_{2} \mathrm{O}_{3}$ contents in both $\mathrm{MKH}$ and $M K S$.

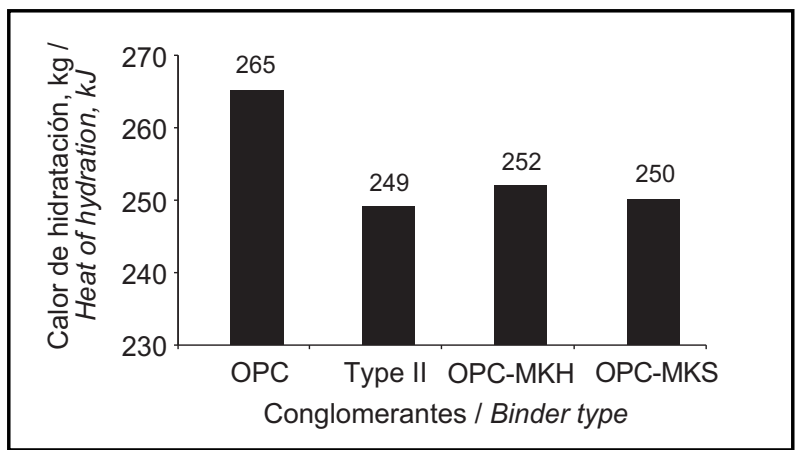

Figura 1. Calor de hidratación de las mezclas con OPC, con cemento de tipo II y con OPC-MK. Figure 1. Heat of hydration for OPC, Type II cement and OPC-MK blends. 


\subsection{Desarrollo de la resistencia a la compresión}

En la Figura 2 se representa la resistencia a la compresión en función del tiempo de curado. Como puede verse, en el hormigón con OPC la mayor resistencia se alcanzó al tercer día. A esa edad, la resistencia a la compresión fue inferior en un 22 y un 24\%, respectivamente, en los hormigones con OPC-MKH y con OPC-MKS, y en un $34 \%$ en la mezcla con cemento de tipo II, en comparación con el hormigón con OPC. En los materiales curados durante 7 días se observó la misma pauta, aunque las diferencias entre el hormigón con OPC y los hormigones con MK fueron menores, del orden del 10 y del $15 \%$. En cuanto al hormigón con cemento de tipo II, este material mostraba la menor resistencia a la compresión a los 7 días, al ser un $16 \%$ inferior que la del hormigón con OPC.

La resistencia a la compresión observada a los 28 días apenas presentaba una pequeña diferencia entre el hormigón con OPC y los demás hormigones, mientras que el hormigón con OPC-MKH demostró ser más resistente que el hormigón con OPC y con cemento de tipo II, en un 3 y un $9 \%$, respectivamente. A dicha edad la resistencia a la compresión más baja se observó en hormigón con OPC-MKS, siendo su valor un $11 \%$ inferior al hormigón con OPC. La pauta observada en las muestras de 90 días fue parecida, salvo que los valores de resistencia de los hormigones con OPC y con OPC-MKH fueron iguales entre sí y un $5 \%$ superiores a los obtenidos con el hormigón con cemento de tipo II. El peor rendimiento se observó en el hormigón con OPC-MKS, que obtuvo un valor de resistencia inferior en un $17 \%$ al del hormigón con OPC-MKH.

El hormigón con OPC-MKH siguió mejorando su resistencia con el tiempo y obteniendo valores parecidos a los del hormigón con OPC hasta los 360 días, momento en el cual la diferencia entre sus valores correspondientes de resistencia fue mínimo. También siguió aumentando con el tiempo la resistencia del hormigón con OPC-MKS, que se incrementó a mayor velocidad entre los 90 y 360 días que en los primeros 90. La diferencia de resistencia a los 360 días entre los dos hormigones con OPC-MK fue de tan solo un 7\%.

Hasta los 28 días, el hormigón con OPC-MKH mostró menor resistencia que el hormigón con OPC, mientras que los valores de ambos materiales fueron equiparables a partir de los 28 días y hasta los 360 . El hormigón con OPC-MKH se mostró más resistente que el hormigón con cemento de tipo II hasta los 180 días, aunque a partir de esta última edad la resistencia de ambos fue parecida. Por el contrario, la resistencia a la compresión del hormigón con OPC-MKS fue considerablemente inferior que las de los hormigones con OPC y con cemento de tipo II hasta los 180 días, aunque esta diferencia se redujo a tan solo un $5 \%$ a los 360 días.

\subsection{Compressive strength development}

Compressive strength is plotted against curing age in Figure 2, which shows that three-day strength was highest in OPC concrete. At that age, compressive strength was 22 and $24 \%$ lower in OPC-MKH and OPCMKS concretes, respectively, and 34\% lower in Type II cement mixes than in OPC concrete. The same pattern was observed in the 7-day materials, although the percentage difference between the OPC and $M K$ concretes narrowed to 10 and 15\%. Type II concrete, in turn, exhibited the lowest 7-day compressive strength: $16 \%$ lower than OPC concrete.

Only a small difference was observed in the 28-day compressive strength values for the OPC the other concretes, while OPC-MKH concrete proved to be stronger than the OPC and Type II concretes by 3 and 9\%, respectively. At this age, the lowest compressive strength was recorded for OPC-MKS concrete, with a value $11 \%$ lower than OPC concrete. The pattern observed in the 90-day specimens was similar, except that the strength values for the OPC and OPC-MKH concretes were equal and 5\% higher than in Type II concrete. The poorest performance was found for OPC$M K S$ concrete, with a strength value $17 \%$ lower than in OPC-MKH.

OPC-MKH concrete continued to gain strength over time, with values similar to the findings for OPC concrete up to 360 days, when the difference in strength was marginal. OPC-MKS concrete strength also continued to grow with age, at a higher rate from 90 to 360 days than earlier. The difference in 360-day strength between the two OPC-MK concretes was only $7 \%$.

Up to 28 days, OPC-MKH concretes exhibited lower strength than OPC concrete, while the values were comparable for the two materials after 28 and up to 360 days. OPC-MKH concrete was stronger than Type II concrete up to 180 days and similar thereafter. In contrast, the compressive strength of OPC-MKS concrete was significantly lower than OPC and Type II concretes up to 180 days, although this difference narrowed to only $5 \%$ after 360 days. 


\subsection{Resistencia a tracción indirecta}

La Figura 3 muestra la evolución de la resistencia a tracción indirecta de las muestras de hormigón a medida que aumentaba la edad de curado. Como ocurría con la resistencia a la compresión, la mayor resistencia a tracción a los 3 días se observó en el caso del hormigón con OPC, seguido del hormigón con OPC-MKH, que presentaba un valor inferior al primero en un $10 \%$. El hormigón con OPC-MKS presentaba la menor resistencia a tracción, con valores inferiores en un 23 y un $11 \%$ respectivamente a los obtenidos con los hormigones con OPC y con cemento de tipo II. Este mismo orden se mantuvo en el caso de las muestras de 7 días: el hormigón con OPC mostró la mayor resistencia y el hormigón con OPC-MKS, la menor. Los hormigones con OPC-MKH y con OPC presentaron una resistencia a tracción similar a los 28 días, que era un $10 \%$ superior a la del hormigón con cemento de tipo II. El hormigón con OPC-MKS presentaba la menor resistencia a tracción, con valores inferiores en un 12 y un $3 \%$ a los obtenidos con los hormigones con OPC y con cemento de tipo II, respectivamente. En edades más tardías (90 días), aumentó la resistencia a tracción de todas las mezclas. El hormigón con OPC-MKH, con 4,5 $\mathrm{MPa}$, obtuvo el valor más próximo al del hormigón con OPC, mientras que la menor resistencia se observó en el hormigón con OPC-MKS (4,1 MPa). No obstante, la diferencia en la resistencia a tracción entre los hormigones con OPC-MKS y OPC fue inferior al $8 \%$.

\subsection{Splitting tensile strength}

Figure 3 shows the variation in splitting tensile strength of concrete specimens with curing age. As in compressive strength, the highest three-day tensile strength was observed for OPC concrete, followed by OPC-MKH concrete, with a value $10 \%$ lower. OPC-MKS concrete exhibited the lowest tensile strength, which was 23 and 11\% lower than the values for OPC and Type II concrete, respectively. The order was the same for the seven-day specimens, with OPC concrete showing the highest and OPC-MKS the lowest strength values. OPCMKH and OPC concrete had similar 28-day tensile strength, which was $10 \%$ higher than in Type II concrete. OPC-MKS concrete tensile strength was 12 and $3 \%$ lower in OPC-MKS than in OPC and Type II concretes, respectively. At later ages (90 days), tensile strength increased in all the concrete mixes. OPC-MKH concrete, at 4.5 MPa, was closest to the OPC concrete value, while strength was lowest in OPC-MKS (4.1 MPa). Nonetheless, the difference in tensile strength between OPC-MKS and OPC concretes was under $8 \%$.

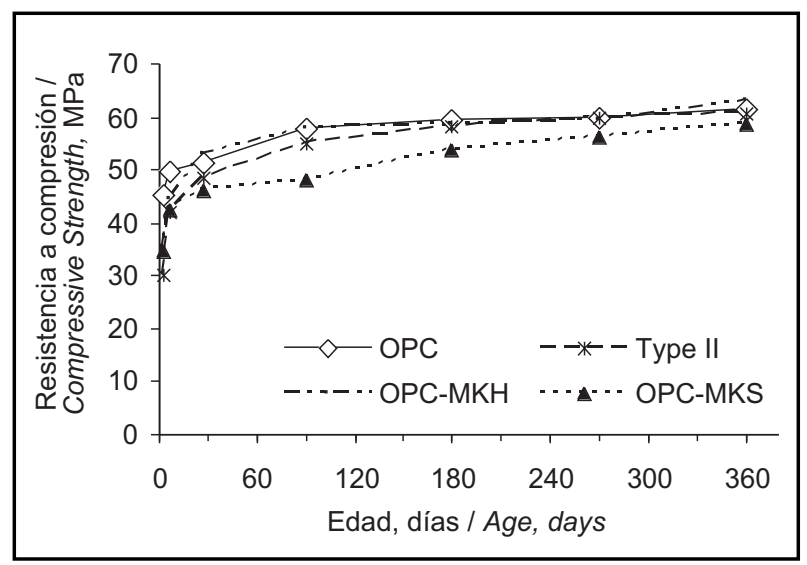

Figura 2. Desarrollo de la resistencia a la compresión de hormigones con OPC, con cemento de tipo II y con OPC-MK. Figure 2. Compressive strength development in OPC, Type II cement and OPC-MK concretes.

Como ocurría con la resistencia a la compresión, durante los primeros 28 días, el hormigón con OPC-MKH mostró menor resistencia a tracción indirecta que el hormigón con OPC, mientras que los valores de resistencia de ambos materiales fueron equiparables a partir de los 28 días y hasta los 90 . Por contra, la resistencia a tracción fue significativamente inferior en el hormigón con OPCMKS que en los hormigones con OPC y con cemento de
As in compressive strength, during the first 28 days, OPC-MKH concrete had lower splitting tensile strength than OPC concrete, while the strength values for the two materials were comparable thereafter and up to 90 days. In contrast, tensile strength was significantly lower in OPC-MKS than in OPC and Type II concretes for the first 90 days. In OPC-MKH and OPC-MKS concretes, splitting tensile strength came to about 7 
tipo II durante los primeros 90 días. En los hormigones con OPC-MKH y con OPC-MKS, la resistencia a tracción indirecta resultó ser aproximadamente el $7 \%$ de la resistencia a la compresión. Esto concuerda con los resultados observados por Kim y otros (27).

Además de los anteriores resultados (resistencias a la compresión y a tracción), puede deducirse que el desarrollo de la resistencia en el hormigón con OPC depende principalmente de la velocidad de hidratación del clínker, mientras que en las mezclas con OPC-MK depende de una combinación de la hidratación del OPC y de la actividad puzolánica del metacaolín. Según la bibliografía, los factores que más influyen en el efecto del metacaolín sobre la resistencia son: (a) el efecto de filler, (b) el efecto de dilución y (c) la reacción puzolánica entre el metacaolín y el $\mathrm{CaOH}$ (23). Las diferencias significativas en el contenido de $\mathrm{SiO}_{2}$ y $\mathrm{Al}_{2} \mathrm{O}_{3}$ de los dos metacaolines locales estudiados, dieron lugar a diferencias en el desarrollo de sus respectivas resistencias, así como entre ambos metacaolines y el metacaolín con un contenido óptimo de alúmina y sílice. La baja resistencia a los 7 días del hormigón con OPC-MKH en comparación con el hormigón con OPC puede deberse al efecto de dilución. Transcurridos 28 días, la resistencia aumentó claramente en el primero, debido principalmente a la reacción puzolánica provocada por el metacaolín, hecho confirmado en un estudio anterior (20) mediante el análisis térmico diferencial (ATD). La resistencia del hormigón con OPC-MKS alcanzó su valor máximo a los 180 días. Esta diferencia de comportamiento puede atribuirse a la baja reactividad de este material, observada en el estudio previo anteriormente mencionado (20). per cent of compressive strength. This concurs with findings reported by Kim et al. (27).

Further to the above results (compressive and tensile strengths), strength development in OPC concrete can be deduced to be mainly dependent on the clinker hydration rate, while in OPC-MK systems it depends on the combination of OPC hydration and the pozzolanic activity of metakaolin. According to the literature, the factors that primarily affect metakaolin contribution to strength are: (a) the filler effect, (b) the dilution effect and (c) the pozzolanic reaction between metakaolin and $\mathrm{CaOH}$ (23). The significant differences in the $\mathrm{SiO}_{2}$ and $\mathrm{Al}_{2} \mathrm{O}_{3}$ content of the two local metakaolins studied led to differences in their strength development and to differences between both and metakaolin with an optimum alumina and silica content. Low 7-day strength in OPC-MKH compared to OPC concrete may be attributed to the dilution effect. After 28 days, strength clearly rose in the former, due mainly to the pozzolanic reaction induced by the metakaolin. Acceleration of this reaction was confirmed by differential thermal analysis (DTA) in a prior study (20). OPC-MKS concrete strength reached its maximum value after 180 days. This difference in behaviour can be attributed to the low reactivity of this material, reported in the aforementioned prior study (20).

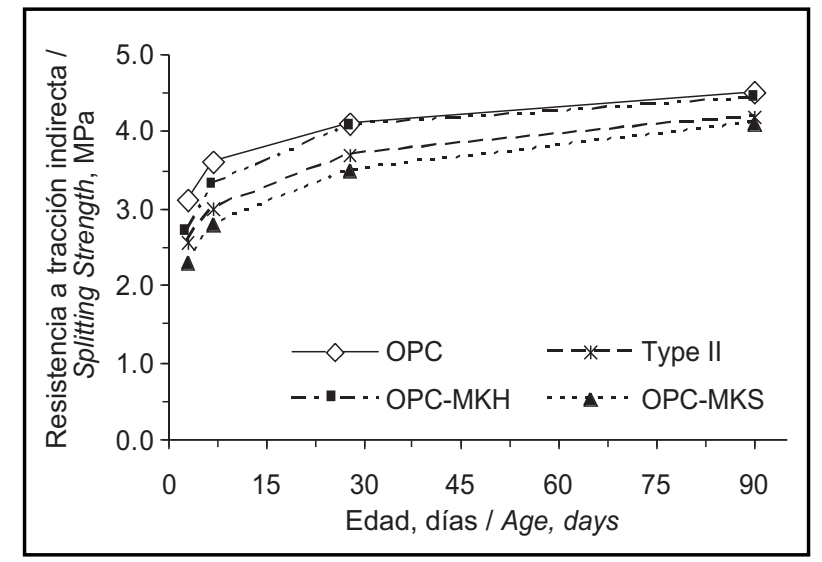

Figura 3. Resistencia a tracción indirecta de hormigones con OPC, con cemento de tipo II y con OPC-MK. Figure 3. Splitting tensile strength in OPC, Type II and OPC-MK concretes.

\subsection{Evolución de la resistencia a la compresión en medios agresivos}

Las Figuras 4 y 5 muestran la evolución de la resistencia a la compresión durante los 360 días que duró el ensayo.

\subsection{Variations in compressive strength under aggressive attack}

Figures 4 and 5 show the variations in compressive strength over the 360-day trial period, expressed as a 
Dicha evolución se expresa como porcentaje de la resistencia inicial (la resistencia a los 28 días de las muestras curadas en agua). Todos los hormigones estudiados se sometieron a dos soluciones agresivas (una de $\mathrm{NaCl}$ al $3 \%$ y otra de $\mathrm{NaCl}$ al $3 \%+\mathrm{Na}_{2} \mathrm{SO}_{4}$ al $5 \%$ ).

La resistencia aumentó durante los primeros 180 días en el hormigón con OPC sometido al ataque de $\mathrm{NaCl}$, pero luego descendió durante los 180 siguientes hasta una resistencia a la compresión de 55,8 MPa. La resistencia del hormigón elaborado con cemento de tipo II también se incrementó de forma continuada hasta los 270 días, pero luego descendió hasta un valor de 60,3 MPa a los 360 días. Ambos hormigones con OPC-MK presentaron aumentos de resistencia hasta los 270 días y, al final de los 360 días, los valores de las mezclas con OPC-MKH y con OPC-MKS fueron 64,1 y 54,4 MPa, respectivamente. Así, ante el ataque de $\mathrm{NaCl}$, fueron los hormigones con cemento de tipo II y con OPC-MKH los que obtuvieron las mayores resistencias a los 360 días. Por otra parte, la resistencia alcanzada por estos dos materiales fue parecida a la registrada en las muestras curadas en agua en las distintas edades. Sin embargo, sería necesaria someter el hormigón con OPC-MKH al ataque del cloruro durante un período más prolongado para evaluar su comportamiento. percentage of the initial strength (28-day strength of water-cured specimens). All the concretes studied were exposed to two aggressive solutions (3\% NaCl and 3\% $\mathrm{NaCl}+5 \% \mathrm{Na}_{2} \mathrm{SO}_{4}$ solutions).

Strength increased in the OPC concrete exposed to the $\mathrm{NaCl}$ solution during the first 180 days, but declined in the following 180. At 360 days, OPC concrete had a compressive strength of $55.8 \mathrm{MPa}$. Type II concrete strength also rose steadily up to 270 days and reached 60.3 MPa after 360. Both OPC-MK concretes exhibited strength rises up to 270 days, with final 360-day values of 64.1 and $54.4 \mathrm{MPa}$ for OPC-MKH and OPC-MKS, respectively. The highest 360-day strengths for the materials exposed to an $\mathrm{NaCl}$ solution, then, were recorded for Type II and OPC-MKH concretes. Moreover, the strength attained by both these materials was similar to the values recorded for the water-cured specimens at each age. Nevertheless, longer exposure would be required to assess the performance of OPC-MKH under chloride attack.

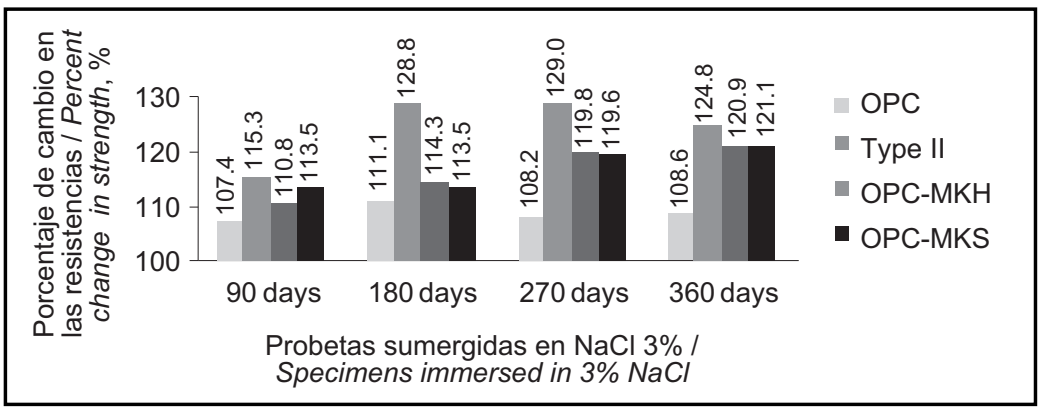

Figura 4. Evolución de la resistencia a la compresión de las mezclas de hormigón sumergidas en una solución de $\mathrm{NaCl}$ al 3\%, expresada como porcentaje de la resistencia inicial (la resistencia a los 28 días de las muestras curadas en agua).

Figure 4. Variations in the compressive strength of concrete mixes immersed in a $3 \% \mathrm{NaCl}$ solution, expressed as a percentage of initial strength (strength of 28-day strength of water-cured specimens)

En la Figura 5 se muestra el efecto de un ataque salino combinado $\left(\mathrm{Na}_{2} \mathrm{SO}_{4}\right.$ al $5 \%+\mathrm{NaCl}$ al $\left.3 \%\right)$ sobre la resistencia a la compresión de los hormigones objeto de estudio. Hasta cierta edad, la resistencia fue mayor que la inicial para todos los hormigones. La resistencia del hormigón con OPC aumentó hasta los 180 días, momento en el que alcanzó $58,9 \mathrm{MPa}$ (un $114 \%$ de su resistencia inicial) para luego descender hasta $55,1 \mathrm{MPa}$ a los 360 días (un $107 \%$ de su valor inicial). La misma pauta se observó en el hormigón con cemento de tipo II, cuya resistencia aumentó hasta los 180 días, momento en el que alcanzó un $124 \%$ del valor inicial, para luego disminuir a edades posteriores. Tras 360 días en contacto con la solución de sulfato-cloruro, la resistencia a la compresión del hormigón con cemento de tipo II
The effect of a combined salt attack (5\% Na $\mathrm{SO}_{4}+3 \%$ $\mathrm{NaCl}$ ) on the compressive strength of the concretes studied is shown in Figure 5. Strength was higher than the initial value in all the concretes up to a certain age. OPC concrete strength increased up to 180 days, when it reached $58.9 \mathrm{MPa}$ or $114 \%$ of its initial strength. Strength declined at later ages, to $55.1 \mathrm{MPa}$ at 360 days (107\% of the initial value). The same pattern was observed in Type II concrete, with strength rising up to 180 days, when it reached $124 \%$ of the initial value, followed by a decline at later ages. After 360 days of exposure to sulfate-chloride, the compressive strength of 
se redujo hasta los 56,1 $\mathrm{MPa}$, lo que supone una Pérdida del $6,5 \%$ respecto al valor máximo, obtenido a los 180 días.
Type II concrete fell to $56.1 \mathrm{MPa}$, a percentage loss of $6.5 \%$ over the 180 -day peak value.

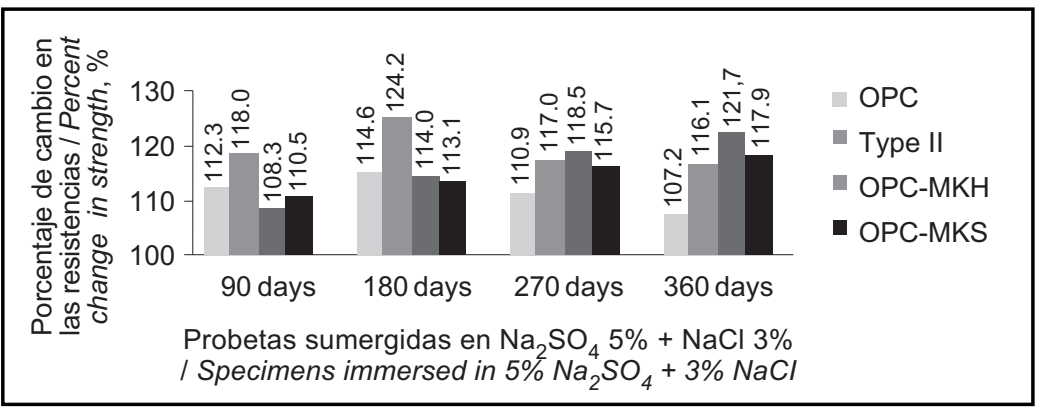

Figura 5. Evolución de la resistencia a la compresión de las mezclas de hormigón sumergidas en una solución de $\mathrm{NaCl}$ al $3 \%+\mathrm{Na}_{2} \mathrm{SO}_{4}$ al $5 \%$, expresada como porcentaje de la resistencia inicial (la resistencia a los 28 días de las muestras curadas en agua).

Figure 5. Variations in compressive strength of concrete mixes immersed in a $3 \% \mathrm{NaCl}+5 \% \mathrm{Na}_{2} \mathrm{SO}_{4}$ solution, expressed as a percentage of initial strength (28-day strength of water-cured specimens).

La resistencia del hormigón con OPC-MK siguió aumentando hasta los 360 días, aunque la velocidad a la que lo hacía no fue uniforme a lo largo del periodo del ensayo. En la Figura 6 se compara la evolución de la resistencia a la compresión de los hormigones con OPC-MKH y con OPC-MKS curados en agua durante 360 días con la evolución de la resistencia observada en los mismos materiales sumergidos en la solución de sulfato-cloruro. Los hormigones con OPC-MK curados en agua siguieron la pauta anteriormente descrita. Cuando se sumergía en una solución de sulfato-cloruro, la resistencia del hormigón con OPC-MKH alcanzó el 118,5 y el 121,7\% de su resistencia inicial a los 270 y 360 días, respectivamente. Como se puede ver en la Figura 6, la resistencia del hormigón aumentó a una velocidad prácticamente uniforme hasta los 270 días, aunque la evolución fue más lenta en las edades posteriores.

Se observó el mismo comportamiento en el hormigón con OPC-MKS sumergido en solución de sulfato-cloruro: la resistencia aumentó un 115,7 y un $117,9 \%$ respecto a la resistencia inicial a los 270 y 360 días, respectivamente, pero la velocidad a la que ésta aumentaba también fue menor pasados los 270 días, como se puede apreciar en la Figura 6. Es de destacar que tras estar sumergido durante 360 días en una solución de sulfato-cloruro, el hormigón con OPC-MKH presentaba mayor resistencia que el hormigón con OPC-MKS. Asimismo, la resistencia a la compresión fue mayor en ambos hormigones con OPC-MK que en los hormigones con OPC o con cemento de tipo II. Los resultados de este estudio demostraron que la presencia de MK reducía el deterioro causado por el ataque del sulfato, independientemente de la composición química del $\mathrm{MK}$, lo cual concuerda con los resultados de la ATD (20).
OPC-MK concrete continued to gain strength up to 360 days, although the rate of strength gain was not uniform during the trial period. Figure 6 compares the variation in the compressive strength of water-cured OPC-MKH and OPC-MKS concretes over 360 days to the strength changes observed in the same materials immersed in sulfate-chloride solution. Water-cured OPC-MK concretes followed the pattern described above. When immersed in a sulfate-chloride solution, OPC-MKH concrete strength increased to 118.5 and $121.7 \%$ of its initial strength after 270 and 360 days, respectively. As Figure 6 shows, the concrete gained strength at a nearly uniform rate up to 270 days but more slowly at later ages.

The same behaviour was observed in OPC-MKS concrete immersed in a sulfate-chloride solution, with strength gains of 115.7 and $117.9 \%$ of the initial strength after 270 and 360 days, respectively. The rate of the gain also declined after 270 days, as shown in Figure 6. Note that after 360 days of immersion in sulfate-chloride solution, OPC-MKH concrete exhibited higher strength than OPCMKS concrete. Moreover, compressive strength was higher in both OPC-MK concretes than in OPC and Type II concretes. The results of this study showed that the presence of MK limited the damage caused by sulfate attack, regardless of the chemical composition of the $M K$. This concurs with the DTA findings (20). 


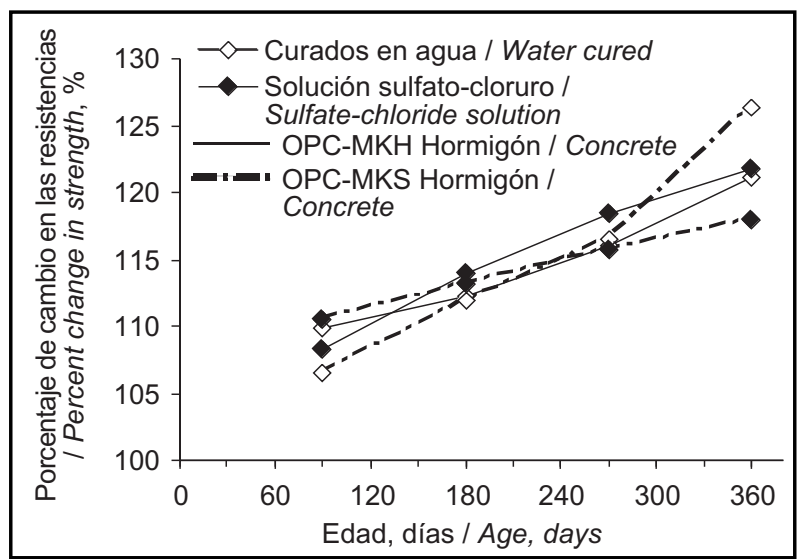

Figura 6. Evolución de la resistencia a la compresión de los hormigones con OPC-MKH y con OPC-MKS curados en agua y sumergidos en una solución de sulfato-cloruro durante 360 días.

Figure 6. Variation in compressive strength of OPC-MKH and OPC-MKS concretes cured in water and immersed in sulfate-chloride solution for 360 days.

\subsection{Perfiles de concentración de cloruros}

En las Figuras 7 y 8 se muestran los perfiles de concentración de cloruros a distintas profundidades obtenidos a los 360 días en los hormigones sumergidos en soluciones de $\mathrm{NaCl}$ al 3,0\% y de $\mathrm{Na}_{2} \mathrm{SO}_{4}$ al 5,0\% $+\mathrm{NaCl}$ al 3,0\%. En estas figuras, los contenidos de cloruro libre y cloruro total en los hormigones con cemento de tipo II, OPC$\mathrm{MKH}$ y con OPC-MKS se expresan como porcentaje del peso del cemento. Los valores indicados son el promedio obtenido de tres mediciones.

De acuerdo con los resultados obtenidos, el contenido de cloruro libre era mayor en el hormigón con cemento de tipo II que en los hormigones con OPC-MK en las capas exteriores (hasta $30 \mathrm{~mm}$ ) pero igual en las interiores (30-50 mm). El hormigón con OPC-MKH tenía el menor contenido de cloruro libre en las capas superficiales (hasta $20 \mathrm{~mm}$ ), mientras que en la capa interior (20-50 $\mathrm{mm}$ ) el contenido de cloruro libre fue igual para los hormigones con OPC-MKH y con OPC-MKS. Los perfiles de cloruro total mostrados en la Figura 7 siguieron por lo general la misma pauta que los perfiles de cloruro libre, aunque el contenido fue mayor en el hormigón con OPCMKH que en el hormigón con OPC-MKS. Los hormigones con cemento de tipo II y con OPC-MKS presentaron el mayor y el menor contenido total de cloruros, respectivamente. La diferencia entre el cloruro total presente en la capa superficial $(0-10 \mathrm{~mm})$ en el hormigón con cemento de tipo II y el hormigón con OPC-MK fue menor que la registrada para sus respectivos contenidos de cloruro libre. La divergencia entre los valores de cloruro total fue más pronunciada hasta una profundidad de $30 \mathrm{~mm}$, cuando se observó una reducción más pronunciada del cloruro total en los hormigones con OPC-MK. Como ocurría con los perfiles de cloruro libre, en la capa más profunda (40-50 mm) no se observó una diferencia

\subsection{Chloride concentration profiles}

The 360-day chloride concentration-depth profiles for concretes immersed in $3.0 \% \mathrm{NaCl}$ and $5.0 \% \mathrm{Na}_{2} \mathrm{SO}_{4}+$ $3.0 \% \mathrm{NaCl}$ solutions are shown in Figures 7 and 8, where the values for the free and total chloride contents in Type II cement, OPC-MKH and OPC-MKS concretes are expressed as a percentage of cement weight. The values given are the average of three measurements.

The findings showed that the free chloride content was higher in Type II concrete than in the OPC-MK concretes in the outer layers (up to $30 \mathrm{~mm}$ ) but the same in the inner layers (30 to $50 \mathrm{~mm}$ ). OPC-MKH concrete had the lowest free chloride content in the surface layers (up to $20 \mathrm{~mm})$. The inner layer $(20-50 \mathrm{~mm})$ free chloride content was the same in OPC-MKH and OPC-MKS concretes. The total chloride profiles shown in Figure 7 followed much the same pattern as the free chloride profiles, although the content was higher in OPC-MKH than OPC-MKS concrete. Type II cement and OPC-MKS concrete had the highest and lowest total chloride contents, respectively. The difference in the total chloride present in the surface layer $(0-10 \mathrm{~mm})$ in Type II cement on the one hand and OPC-MK concrete on the other was smaller than the difference recorded for their free chloride content. The separation between the total chloride values was more pronounced up to a depth of $30 \mathrm{~mm}$, however, where a steeper reduction in total chloride was observed for the OPC-MK concretes. As in the free chloride profiles, no significant inter-mix difference in total chloride content was observed in the inner-most layer $(40-50 \mathrm{~mm})$. The difference between the free and total chloride contents is a measure of the binding capacity of cementitious materials. The 
significativa entre el contenido de cloruro total de las distintas mezclas. La diferencia entre los contenidos de cloruro libre y total sirve para medir la capacidad de los materiales cementantes de combinarse con los iones. Los datos experimentales confirmaron que ambos hormigones con OPC-MK, pero especialmente el elaborado con OPC-MKH, se combinaban con los iones cloruro de forma más eficaz que el hormigón con cemento de tipo II, como demuestra la diferencia entre los contenidos de cloruro libre y total en la capa exterior (0-10 mm). A mayor profundidad, la capacidad de combinación resultó ser mayor en el hormigón con cemento de tipo II que en el hormigón con OPC-MKS. Esto se debió no al mejor comportamiento del hormigón con cemento de tipo II que el de los hormigones con OPC-MK, sino a la mayor concentración de iones cloruro que penetraban en las capas más profundas del primero. experimental data confirmed that both OPC-MK concretes, and especially OPC-MKH, bound chloride ions more effectively than Type II concrete, as shown by the difference between the free and total chloride contents in the outer layer $(0-10 \mathrm{~mm})$. At the inner depths, binding capacity was found to be higher in Type II cement than OPC-MKS concrete. This was due to the higher concentration of chloride ions penetrating deeply in Type II concrete rather than to any out-performance of the OPC-MK concretes.

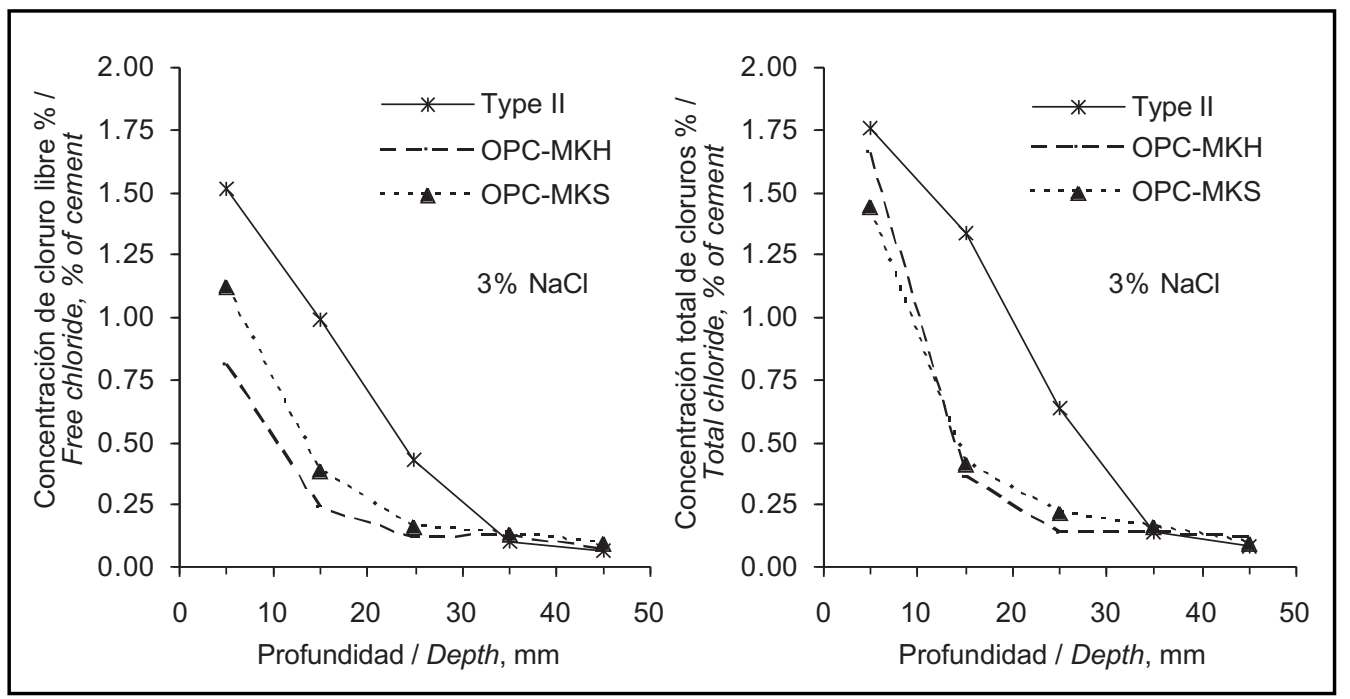

Figura 7. Perfiles de concentración de cloruro libre y total (en \% del peso del cemento) a distintas profundidades en probetas de hormigón sumergidas en una solución de $\mathrm{NaCl}$ al $3 \%$ durante 360 días. Figure 7. Free and total chloride concentration (in per cent of cement, by wt)-depth profiles for concrete mixes immersed in a $3 \% \mathrm{NaCl}$ solution for 360 days.

En la Figura 8 se muestran los perfiles de concentración de cloruros a distintas profundidades obtenidos a los 360 días para los hormigones sumergidos en una solución de sulfato-cloruro $\left(\mathrm{Na}_{2} \mathrm{SO}_{4}\right.$ al $5 \%+\mathrm{NaCl}$ al $\left.3 \%\right)$. Como era de esperar, el hormigón con cemento de tipo II redujo el contenido de iones cloruro libres de forma más eficaz ante el ataque combinado de sulfato y cloruro que ante un ataque solo con cloruro. En el caso del ataque combinado, los perfiles de concentración de cloruro libre a distintas profundidades obtenidos con el hormigón con cemento de tipo II y con OPC-MK fueron parecidos y se produjo un marcado descenso del contenido de cloruro libre entre la capa exterior y las siguientes. El contenido de cloruro libre en la capa exterior (hasta $20 \mathrm{~mm}$ ) fue mayor en el hormigón con cemento de tipo II que en cualquiera de los dos cementos con OPC-MK. En las
The 360-day chloride concentration-depth profiles for concretes immersed in a sulfate-chloride solution (5.0\% $\mathrm{Na}_{2} \mathrm{SO}_{4}+3.0 \% \mathrm{NaCl}$ ) are plotted in Figure 8. As expected, Type II concrete reduced the free chloride ion content more effectively under a combined sulfatechloride attack than in a pure chloride environment. Under combined attack, the free chloride concentrationdepth profiles of Type II cement and OPC-MK concretes were similar, with a steep reduction in the free chloride content between the outer and subsequent layers. The free chloride content in the outer layer to a depth of 20 $\mathrm{mm}$ was higher in Type II concrete than in either of the OPC-MK concretes. In the inner layers, no significant difference was observed. As Figure 8 shows, however, the total chloride content in Type II and MK concretes differed significantly. Total chloride in the outer layer up 
capas interiores no se observó ninguna diferencia significativa. Sin embargo, se constató una diferencia importante entre los hormigones con cemento de tipo II y con MK en relación con el contenido total de cloruro, según se ve en la Figura 8. El cloruro total en la capa exterior (hasta $30 \mathrm{~mm}$ ) fue mayor en el hormigón con cemento de tipo II, mientras que en las capas interiores (30-50 $\mathrm{mm}$ ) fue parecido a los valores registrados en los hormigones con OPC-MK. El menor contenido de cloruro total en la capa exterior (0-10 mm) correspondió al hormigón con OPC-MKS, lo que indica que esta mezcla tenía una mayor capacidad de inmovilizar los iones que el hormigón con OPC-MKS. A mayores profundidades (10-50 mm), el contenido de cloruro total de los hormigones con OPCMKH y con OPC-MKS fue parecido. De acuerdo con la diferencia entre los contenidos de cloruro libre y total presentes en la capa exterior, la capacidad de combinar con los iones fue parecida en los hormigones con OPC$\mathrm{MKH}$ y con cemento de tipo II. En cuanto al hormigón con OPC-MKS, este material presentaba la menor capacidad de combinación con los iones cloruro. to a depth of $30 \mathrm{~mm}$ was greater in Type II concrete, while in the inner layers $(30-50 \mathrm{~mm})$, it was similar to the values recorded for OPC-MK concretes. The lowest total chloride content in the outer layer $(0-10 \mathrm{~mm})$ was found for OPC-MKS concrete, an indication that OPC-MKH concrete had higher binding capacity. In the inner depths $(10-50 \mathrm{~mm})$, the total chloride content was similar in OPC-MKH and OPC-MKS concretes. Based on the difference between the free and total chloride contents in the outer layer, the binding capacities of OPC-MKH and Type II concrete were similar. OPC-MKS concrete, in turn, exhibited the lowest binding capacity.

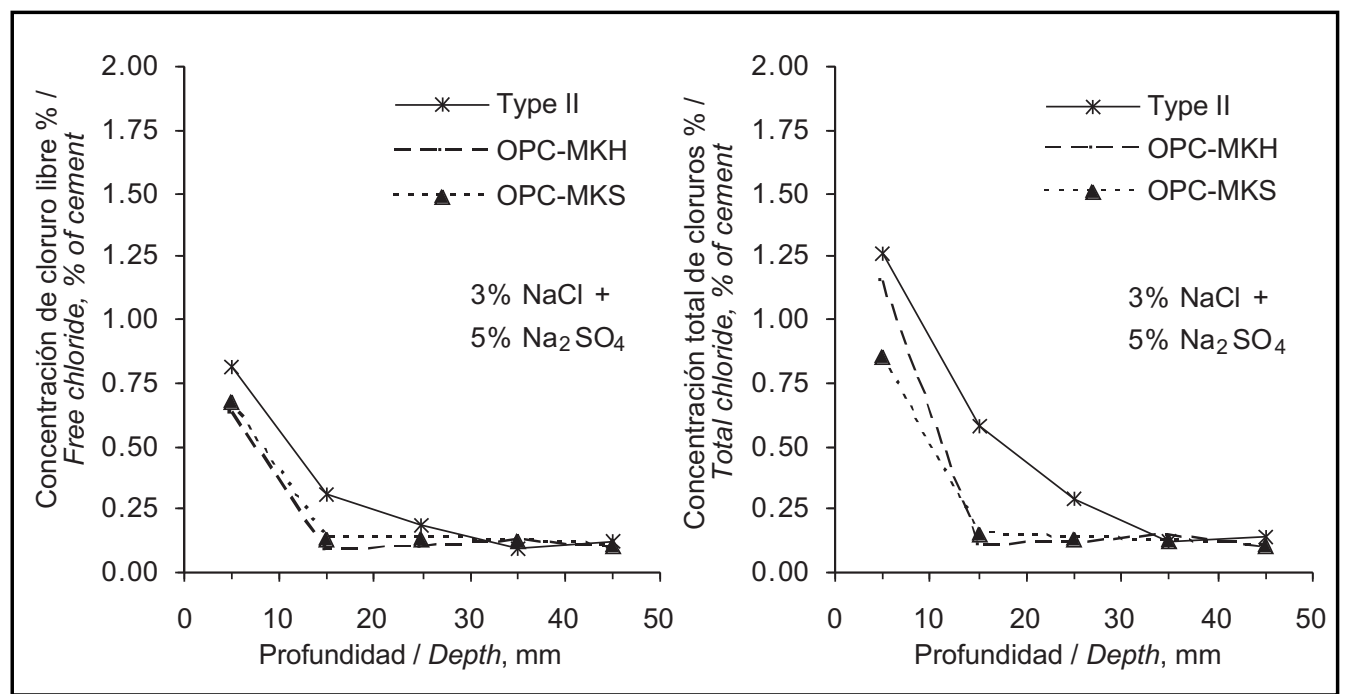

Figura 8. Perfiles de concentración de cloruro libre y total (en \% del peso del cemento) a distintas profundidades en muestras de hormigón sumergidas en una solución de $\mathrm{NaCl}$ al 3\% $+\mathrm{Na}_{2} \mathrm{SO}_{4}$ al $5 \%$ durante 360 días.

Figure 8 Free and total chloride concentration (in percent of cement, by wt) -depth profiles for concrete mixes immersed in a $3 \% \mathrm{NaCl}+5 \% \mathrm{Na}_{2} \mathrm{SO}_{4}$ solution for 360 days.

\subsection{Resistencia a la penetración de cloruros}

En la Figura 9 se muestran los resultados del ensayo rápido de penetración de cloruros. En ella, cada valor representa el promedio obtenido de tres mediciones. La adición de metacaolín a las mezclas produjo un aumento considerable de la resistencia del hormigón a la penetración de cloruros. La carga pasada en el ensayo rápido de penetración de cloruros en los hormigones con OPCMK, entre 639 y 666 culombios, indica una permeabilidad muy baja a los iones cloruro, mientras que la carga pasada en los hormigones con OPC y con cemento de tipo II,

\subsection{Resistance to chloride penetration}

The results of the rapid chloride penetration test are shown in Figure 9, where each value is the average of three measurements. Adding metakaolin to the mixes raised concrete resistance to chloride penetration significantly. The charge passed (in the rapid chloride test) in OPC-MK concretes, from 639 to 666 coulombs, was indicative of very low chloride ion permeability, while the charge passed in OPC and Type II concretes was 2597 and 1008 coulombs, denoting moderate and low chloride ion permeability, respectively. In mixes 
que fue de 2.597 y 1.008 culombios, revela permeabilidades moderada y baja, respectivamente, a los iones cloruro. En las mezclas en las que se empleó MK como sustituto del cemento, la carga pasada fue un 75 y un $35 \%$ inferior de media en los hormigones con OPC y con cemento de tipo II, respectivamente. Estos resultados concuerdan con los obtenidos por Badogiannis y Tsivilis (24). Las pequeñas diferencias observadas entre la capacidad de ambos metacaolines para reducir la permeabilidad a cloruros fueron de escasa relevancia en comparación con la reducción total de permeabilidad a cloruros. Como ya se indicó en un estudio anterior (20), los resultados de la penetración de cloruros proporcionaron pruebas contundentes del efecto del MK en la estructura porosa de la matriz del hormigón, lo que altera considerablemente el transporte de agua y la velocidad de difusión de los iones agresivos. Asimismo, al añadir MK se aumentó la capacidad del sistema para inmovilizar iones cloruro, consiguiendo de este modo reducir el contenido de iones libres. Con ello se disminuye la corrosión la armadura de acero, ya que generalmente se considera a los iones cloruro libres el único elemento en el agua de los poros que afecta a la corrosión de la armadura. where $M K$ was used as a cement replacement, the charge passed was 75 and 35\%, on average, lower than in OPC and Type II concretes, respectively. These results concurred with the findings reported by Badogiannis and Tsivilis (24). The small differences observed between the capacity of the two metakaolins to reduce chloride permeability were of minor significance compared to the total reduction of chloride permeability. As noted in a prior study (20), the chloride penetration findings provided strong evidence of the impact of $M K$ on the pore structure in the concrete matrix, substantially modifying water transport and the diffusion rates of detrimental ions. Furthermore, the addition of $M K$ increased the system's capacity to bind chloride ions, thereby lowering the free ion content. This reduced steel reinforcement corrosion, as free chloride ions are generally acknowledged to be the only species in the pore water that affects reinforcement corrosion.

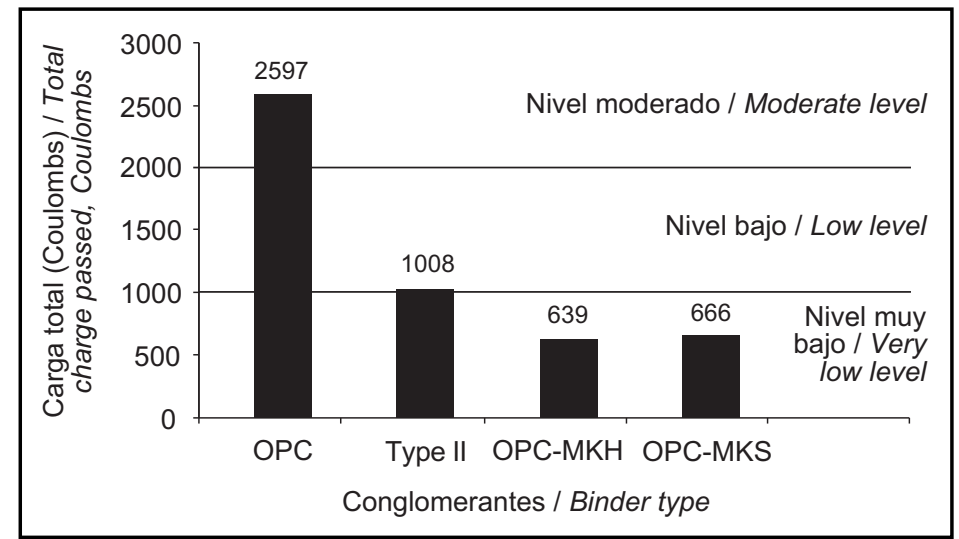

Figura 9. Permeabilidad a iones cloruro de las distintas mezclas de hormigón Figure 9. Chloride ion permeability in concrete mixes.

\section{CONCLUSIONES}

A continuación se detallan las conclusiones que pueden extraerse de los ensayos realizados en este estudio.

1. Los valores observados del calor de hidratación en ambas mezclas de cemento Pórtland ordinario con metacaolín fueron menores que en el hormigón con OPC puro e iguales a las del cemento con calor de hidratación moderado.

2. Debido a su contenido en alúmina y sílice, los metacaolines estudiados tuvieron un efecto muy positivo en la resistencia del hormigón a los 360 y a los 90 días. Este resultado confirmó que ambos tipos de metacaolín

\section{CONCLUSIONS}

The conclusions drawn from the results of the tests conducted in this study are set out below.

1. The heat of hydration values measured were lower in both ordinary Portland cement-metakaolin blends than in the pure OPC and the same as in moderate heat of hydration cement.

2. Based on their alumina and silica contents, the metakaolins studied had a very positive effect on 90- and 360-day concrete strength. This finding confirmed that both types of metakaolin (MKH and MKS) used improved 
empleados (el MKH y el MKS) mejoraron la microestructura del cemento hidratado hasta elevar la resistencia a niveles comparables con los propios del hormigón convencional.

3. La sustitución de cemento por metacaolín aumentó de forma eficaz la resistencia del hormigón al ataque de cloruros. La resistencia del hormigón con metacaolín aumentó durante los primeros 270 días del ensayo.

4. Las mezclas con metacaolín-OPC demostraron ser mucho más duraderas frente al ataque de sulfato-cloruro que aquéllas con cemento Pórtland ordinario o con cemento con calor de hidratación moderado. La resistencia de los hormigones con metacaolín sometidos al ataque de sulfato-cloruro se incrementó de forma continuada durante los 360 días que duró el ensayo.

5. Las diferencias entre los contenidos de cloruro libre y total durante el ataque de sulfato-cloruro, demostraron que la capacidad de unirse a iones cloruro era claramente mayor en el hormigón con OPC-MKH que en el hormigón con cemento de tipo II, mientras que la capacidad de combinación con los iones de este último era parecida a la del hormigón con OPC-MKS.

6. En los ensayos de resistencia a la penetración de cloruros realizados según se especifica en la norma ASTM C 120, se observó que la penetración de cloruros fue un 75 y un 35\% menor en el hormigón con metacaolín que en los hormigones con OPC y con cemento de tipo II como consecuencia de los cambios producidos en la microestructura del cemento hidratado.

En general, los resultados demostraron que pueden obtenerse materiales puzolánicos utilizables mediante la activación térmica de caolín local con un contenido medio de $\mathrm{Al}_{2} \mathrm{O}_{3}$ del $20,0 \%$ y un contenido de $\mathrm{SiO}_{2}$ inferior al $55,0 \%$. Si bien puede usarse caolín local con un contenido de $\mathrm{Al}_{2} \mathrm{O}_{3}$ inferior, cabría esperar en tal caso una acción menos eficaz, en especial en las primeras edades. La gran resistencia y durabilidad del hormigón elaborado con una mezcla de cemento y metacaolín, recomienda su empleo allí donde se precisa de un hormigón duradero, especialmente en entornos en que se propicia el ataque salino combinado. the hydrated cement microstructure, raising strength to levels comparable to the values typical of conventional concrete.

3. Replacing cement with metakaolin effectively enhanced concrete resistance to chloride attack. Metakaolin concrete strength increased during the first 270 days of the trial.

4. Metakaolin-OPC blends proved to be much more durable under sulfate-chloride attack than ordinary Portland and moderate heat of hydration cement. The strength of metakaolin concretes exposed to sulfatechloride attack rose continually through the end of the 360-day trial.

5. The findings on the difference between the free and total chloride contents during sulfate-chloride attack showed that binding capacity was clearly higher in OPCMKH than in Type II concrete, while the binding capacities of the OPC-MKS and Type II concretes were similar.

6. Concrete chloride penetration resistance tests conducted as specified in standard ASTM C 1202 revealed that chloride penetration was 75 and $35 \%$ lower in metakaolin-blended cement concrete than in the OPC and Type II concretes as a result of the microstructural improvement in the hydrated cement.

On the whole, the results showed that effective pozzolanic material can be obtained by thermally activating local kaolin with an average $\mathrm{Al}_{2} \mathrm{O}_{3}$ content of $20.0 \%$ and a $\mathrm{SiO}_{2}$ content of under $55.0 \%$. While local kaolin with an even lower $\mathrm{Al}_{2} \mathrm{O}_{3}$ content may be also used, its action would be expected to be less efficient, especially at early ages. The high strength and long durability of concrete made with metakaolin-blended cement favours its use where durable concrete is required, especially where it may be exposed to a combined salt attack.

\section{BIBLIOGRAFÍA / BIBLIOGRAPHY}

(1) Kostuch, J. A.; Walters, V.; Jones, T. R.: "High performance concretes incorporating metakaolin: a Review", Concrete 2000 (1993), E\&FN Spon, pp. 1799-1811.

(2) Sabir, B. B.; Wild, S.; Khatib, J. M.: "On the workability and strength development of metakaolin concrete", Concrete for Environmental Enhancement and Protection (1996), E\&FN Spon, pp. 651-656.

(3) Curcio, F.; Deangelis, B. A. Pagliolico, S.: "Metakaolin as a pozzolanic microfiller for high-performance mortars", Cem. Concr. Res., vol. 28, no 6 (1998), pp. 803-809. 
(4) Sabir, B. B.; Wild, S.; Bai, J.: "Metakaolin and calcined clay as pozzolans for concrete: a review", Cement and Concrete Composites, vol. 23 (2001), pp. 441-454.

(5) Siddique, R.; Klaus, J.: "Influence of metakaolin on the properties of mortar and concrete: A review", Applied Clay Science, vol. 43, no 3-4 (2009), pp. 392-400.

(6) Bakhshi, M.; Ghalibafian, M.: Properties of high-performance concrete containing high reactivity metakaolin. SP-228, ACI, Farmington Hills, Mich. (2005), pp. 287-296,.

(7) Razak, H. A.; Wong, H. S.: "Effect of incorporating metakaolin on fresh and hardened properties of concrete". SP-200, ACI, Farmington Hills, Mich. (2001), pp. 309-324,.

(8) Justice, J. M.; Kennsion, L. H.; Mohr, B. J.; Beckwith, S. L.; McCormick, L. E.; Wiggins, B.; Zhang, K. Z. Z.; Kurtis, E.: "Comparison of two metakaolins and a silica fume used as supplementary cementitious materials". SP-228, ACI, Farmington Hills, Mich. (2005), pp. 213-236,

(9) Caldarone, M. A; Gruber, K. A.; Burg, R. G.: "High reactivity metakaolin: A new generation mineral admixture", Concrete International, vol. 16, no 11 (1994), pp. 37-40.

(10) Caldarone, M. A.; Gruber, K. A.: "High reactivity metakaolin - a mineral admixture for high-performance concrete", Proceedings of the International Conference on Concrete under Severe Conditions, Environment and Loading, Sapporo, Japan, vol. 2 (1995) pp. 10151024 ,

(11) Zhang, M. H; Malhotra, V. M.: "Characteristics of a thermally activated alumino-silicate pozzolanic material and its use in concrete", Cem.Concr. Res., vol. 25, no 8 (1995), pp. 1713-1725.

(12) Bai, J.; Wild, S.; B. B. Sabir, B. B.; Kinuthia, J. M.: "Workability of concrete incorporating pulverized fuel ash and metakaolin", Magazine of Concrete Research, vol. 51, no 3 (1999), pp. 207-216.

(13) Wild, S.; Khatib, J. M.; Roose, L. J.: "Chemical shrinkage and autogenous shrinkage of Portland cement-metakaolin pastes", Advances in Cement Research, vol. 10, no 3 (1998), pp. 109-119.

(14) Boddy, R.D.; Hooton, K.A.; Gruber: "Long-Term testing of the chloride penetration resistance of concrete containing high reactivity metakaolin", Cem. Concr. Res., vol. 31, no 5 (2001), pp. 759-765.

(15) Justice, J. M.; Kurtis K. E.: "Influence of metakaolin surface area on properties of cement-based materials", ASCE, Journal of Materials in Civil Engineering, vol. 19, no 9 (2007), pp. 762-771.

(16) Balaguru P.: "Properties of normal and high-strength concrete containing metakaolin". SP-199, ACI, Farmington Hills, Mich. (2001), pp. 737-756.

(17) Ramlochan T.; Thomas, M.: "Effect of metakaolin on external sulfate attack". SP-192, ACI, Farmington Hills, Mich. (2000). pp. 239252.

(18) Parande, K.; Babu, B.; Karthik, M. A.; Kumaar, K.K.; Palaniswamy, N.: "Study on strength and corrosion performance for steel embedded in metakaolin blended concrete/mortar", Construction and Building Materials, vol. 22, no 3 (2008), pp. 127-134.

(19) Coleman, N. J.; McWhinnie, W.: "Solid State Chemistry of Metakaolin-Blended Ordinary Portland Cement". Journal of Materials Science, vol. 35, no 11 (2000), pp. 2701-2710.

(20) Abo-El-Enein, S. A.; Abbas, R.; Ezzat, E.: "Properties and durability of metakaolin blended cemens", Mater Construcc, vol. 60, no 299 (2010), pp. 21-35.

(21) Poon, C.S.; Kou, S.C.; Lam, L.: "Compressive strength, chloride diffusivity and pore structure of high performance metakaolin and silica fume concrete", Construction and Building Materials, vol. 20 (2006), pp. 858-865.

(22) Arikan, M.; Sobolev, K.; Ertün, T.; Yeǧinobali, A.; Turker, P.: "Properties of blended cements with thermally activated kaolin", Construction and Building Materials, vol. 23, no 1 (2009), pp. 62-70.

(23) Badogiannis, E.; Kakali, G.; Dimopoulou, G.; Chaniotakis, E.;. Tsivilis, S: "Metakaolin as a main cement constituent: exploitation of poor Greek kaolins", Cement and Concrete Composites, vol. 27 (2005), pp. 197-203.

(24) Badogiannis, E.; Tsivilis,S.: Exploitation of poor Greek kaolins: durability of metakaolin concrete. Cement and Concrete Composites, vol. 31, no 2 (2009), pp. 128-133.

(25) Castellote, M.; Andrade, C.: "Round-Robin test on chloride analysis in concrete - part II: analysis of water soluble chloride content", Materials and Structure, ,vol. 34, no 10 (2001), pp. 589-596.

(26) Castellote, M.; Andrade, C.: "Round-Robin test on chloride analysis in concrete - part I: analysis of total chloride content", Materials and Structure, vol. 34, no 9 (2001), pp. 532-549.

(27) Kim, H. S.; Lee, S. H; Moon, H. Y.: "Strength properties and durability aspects of high strength concrete using Korean metakaolin". Construction and Building Materials, vol. 21, no 4 (2007), pp. 1229-1237. 